cently, while studying the nomenclatorial status of certain genera of Indian fishes, it was found that one of the Ceylonese genera ascribed to different positions in the system by various ichthyologists needed more scrutiny. The genus referred to is Eustira, described by Günther (1868, Cat. Fishes British Mus., $7: 331$ ), to include a new cyprinid fish from Ceylon named by him Eustira ceylonensis. Günther placed Eustira under the group "Abramidina" of the family Cyprinidae and described it briefly as follows: Body oblong, much compressed, the entire abdominal edge being trenchent, scales of moderate size; lateral line abruptly bent downwards behind the pectoral fin; mouth obliquely directed upwards; barbels none. Dorsal fin of moderate length, without spines, opposite the anal; anal fin long, many rayed, caudal fin forked, pectorals elongate; ventrals well developed. Pseudobranchiae; gillrakers fine, lanceolate, rather widely set. Pharyngeal teeth 5.3.2-2.3.5, uncinatc, not denticulated.

The fin rays and scale counts of $E$. ceylonensis were given by Günther as "D. 12. A. 17. V. 7. L. lat. 35. L. transv. $7-1 / 2 / 2$," and the origin of the dorsal fin was noted as being slightly in advance of that of the anal fin. The species was also characterized as having pectoral fins shorter than the head, reaching only as far back as the pelvics.

Because of the slightly inadequate descriptions of the genus and the species, Eustira has been confused with Chela Hamilton, Laubuca Bleeker, and Perilampus Day (nec McClelland), by Day (187578, Fishes of India), Weber and de Beaufort (1916, Fishes of the Indo-Australian Archipelago, 3), Deraniyagala (1930, Eventognathi of Ceylon, and 1952, Coloured Atlas of Some Vertebrates from Ceylon, 1), Smith (1945, Bull. U. S. Nat. Mus., 188), and others. In fact, while recognizing Eustira as a subgenus of Laubuca, Weber and de Beaufort (1916, op. cil., 48) remarked: "We do not think that the genus Eustira is generically distinct from Laubuca; we therefore give it only the value of a subgenus, containing Eustira ceylonensis Gthr. and our Eustira maassi." They distinguished the subgenus Eusitra from Laubuca s. sir., by the downward curvature of the lateral line behind the pectorals, abrupt in Eustira, gentle in Laubuca.

While considering $E$. ceylonensis as a synonym of Chela laubuca Hamilton, Deraniyagala (1930, $o p$. cil.) in a footnote commented on its doubtful similarity to species of Danio; but in his latest work on Ceylon fishes (Deraniyagala, 1952, op. cit.), he once again treated $E$. ceylonensis as a synonym of

THE CEYLONESE CYPRINID GENUS EUSTIRA GÜNTHER CONSIDERED A SYNONYM OF DANIO HAMILTON.-In discussing the classification of the danios, Myers (1953, Aquarium Jour., 24: 235-38) drew attention to numerous gaps that still remain to be filled before final word can be said as to their classification. Re-

\section{Chela laubuca.}

In view of these conflicting views on the systematic position of Eustira and due to the fact that no additional material of the orthotype has been recognized from Ceylon since it was first described, a reexamination of the type material in the British Museum (Natural History) seemed desirable. Fur. 


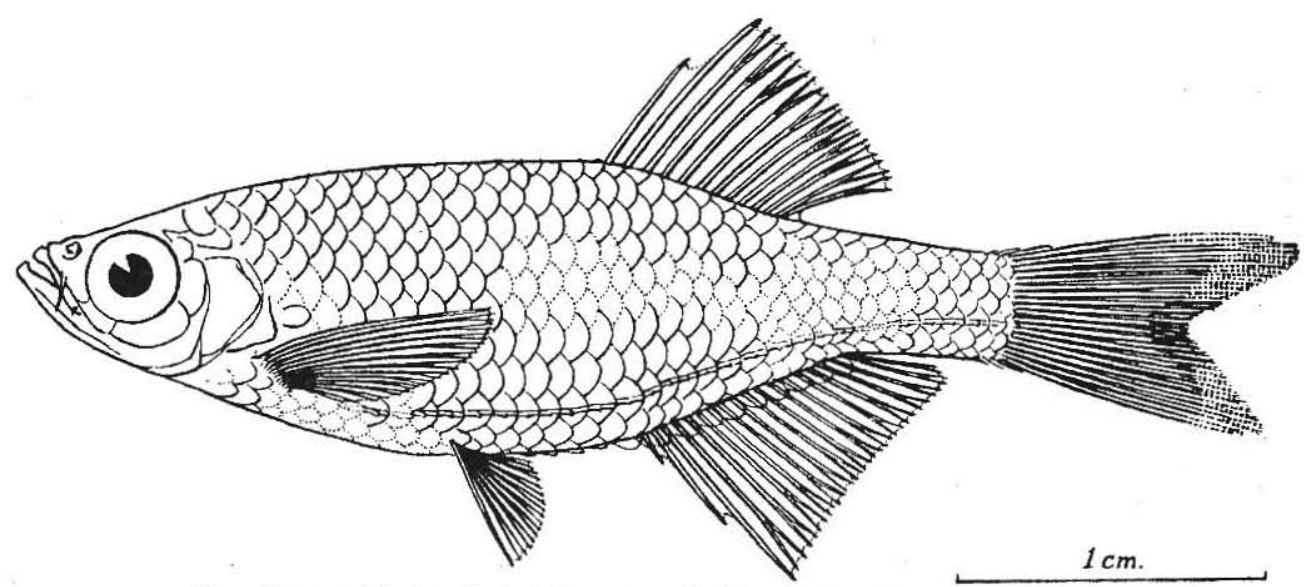

Fig. 1. Danio malabaricus (Jerdon) drawn from the holotype of Eustira ceylonensis Günther

thermore it was felt that this would help in clarifying certain discrepancies in the descriptions of the genus and species by Günther. The type series consists of six specimens cited as purchased from Mr. Cumming, from Ceylon.

While on a visit to England, the late Dr. S. L. Hora kindly examined for me the types of $E$. ceylonensis in the British Museum. In a letter dated September 23, 1953 he informed me that in "Günther's specimens the origin of $\mathrm{D}$. is slightly in advance of A.; number of branched anal rays 15; scales transversely $8 / 1 / 2$." No figure of E. ceylonensis has been published. This deficiency has now been remedied by an excellent figure of the type specimen (Fig. 1), sent to me by Dr. Ethelwynn Trewavas of the British Museum. The two pairs of rudimentary barbels, present in the specimens and shown in the drawing, escaped Günther's attention, for he characterized Eustira as being devoid of barbels. During my visit to the British Museum in July, 1955, I was able to reexamine once again the type material and to verify the points mentioned above. I now find that in the following important characters Eustira differs from Chela as the latter genus is defined at present (Silas, MS).

1. The dorsal fin originates ahead of the anal fin, rather than behind the front of that fin.

2. There are two pairs of barbels (none in Chela).

3. The pectoral fins are shorter than the head, instead of being elongate and much longer than the head.

4. The abdominal margin is rounded, rather than being keeled.

Eustira is obviously distinct from Chela, and its rounded abdominal margin separates it from all other cultrate genera of the subfamily Abramidinae. The combination of characters mentioned above places Eustira in the Rasborinae. In fact, Eustira fully agrees with the description of one of the wellknown genera in this subfamily, namely Danio Hamilton. There is not a single character by which the two nominal genera can be said to differ. Hence I propose that Eustira be considered a synonym of Danio.

Only one species of Danio, namely D. malabaricus (Jerdon) is known at present from Ceylon, although the exact status of the Ceylonese form in relation to the typical form of the Cauvery drainage in southern India needs elucidation. The type specimen of $E$. ceylonensis, figured here, shows in addition to the two pairs of barbels, the following characters not noted by the original author: the pelvic fin has 8 rays (i, 7$)$; the anal fin has 18 rays (iii, 15 ), the last ray divided to the base; the caudal fin has 19 rays. Taking all these data into consideration, there is not a single character by which $E$. ceylonensis can be separated from the Ceylonese form, or representative, of Danio malabaricus, to the synonymy of which it is here relegated.

The subgenus of Laubuca to which Weber and de Beaufort misadvisedly assigned the name Eustira is thus left without a valid name. The problem is under further study.

I wish to thank Dr. Carl L. Hubbs for going through the manuscript and Drs. Sunder Lal Hora and Ethelwynn Trewavas for the help rendered.E. G. SLAS, Scripps Institution of Oceanography, La Jolla, California. 